\title{
REgister Nelayan di desa mUNJUNGagung, KRAMAT, tegal
}

\author{
Leli Triana, Khusnul Khotimah \\ Universitas Pancasakti Tegal \\ lelitriana99@gmail.com
}

Pertama diterima : 7 Juni 2021

Bukti akhir diterima : 30 Juni 2021

\begin{abstract}
Abstrak
Penelitian ini mengkaji register nelayan di Desa Munjungagung, Kramat, Tegal. Tujuan penelitian ini adalah mendeskripsikan bentuk register nelayan di Desa Munjungagung, Kramat, Tegal dan mendeskripsikan faktor-faktor penyebab munculnya register nelayan di desa tersebut. Penelitian ini menggunakan metode kualitatif deskriptif. Metode penyediaan data dalam penelitian ini adalah metode simak dengan teknik sadap sebagai teknik dasar dan teknik simak libat cakap serta teknik catat sebagai teknik lanjutannya. Metode analisis data dalam penelitian ini adalah metode padan translasional dan metode padan pragmatis. Penyajian hasil analisis data dengan menggunakan metode informal. Hasil penelitian menunjukkan bahwa: 1) register nelayan Desa Munjungagung berbentuk kosakata khas yang termasuk dalam kelas kata nomina, adjektiva, dan verba, 2) faktor penyebab digunakannya register nelayan adalah faktor sosial dan situasional. Faktor sosial berupa jenis pekerjaan yang sama yaitu nelayan, sedangkan faktor situasionalnya meliputi: penutur dan mitra tutur, sama-sama berprofesi sebagai nelayan, tempat terjadinya pembicaraan di sekitar pantai, waktu pembicaraan pada saat mereka tidak melaut, dan pokok pembicaraannya berkisar tentang dunia nelayan.

Kata Kunci : variasi bahasa, register nelayan, Munjungagung
\end{abstract}

\section{LATAR BELAKANG}

Bahasa memiliki peranan yang sangat penting dalam proses komunikasi. Bahasa adalah sistem lambang bunyi yang arbitrer yang dipergunakan oleh masyarakat untuk bekerja sama, berinteraksi, dan mengidentifikasi diri. Maksud dari istilah arbitrer itu adalah tidak adanya hubungan wajib antara lambang bahasa yang berwujud bunyi dengan konsep atau pengertian yang dimaksud oleh lambang tersebut (Chaer 2014: 45).

Variasi bahasa terjadi karena masyarakat yang heterogen dan kegiatan masyarakat yang heterogen pula. Variasi bahasa dapat dibedakan dari segi penutur, pemakaian, keformalan, dan sarana (Chaer 2010: 62-73). Berdasarkan penuturnya, varasi bahasa dibedakan menjadi idiolek, dialek, kronolek, dan sosiolek. Variasi bahasa dari segi pemakaian, penggunaannya, atau fungsinya disebut fungsiolek, ragam, atau register. Variasi bahasa dari segi keformalan dibedakan menjadi ragam beku (frozen), ragam resmi (formal). Ragam usaha (konsultatif), ragam santai (casuel), dan ragam akrab (intim). Variasi bahasa yang dipergunakan oleh sekelompok orang terkait dengan bidang pekerjaan atau profesi disebut register.

Istilah register menurut Pateda (1987: 64-65) adalah pemakaian bahasa yang berhubungan dengan pekerjaan seseorang. Ada lima jenis register, yakni register beku, formal, konsultatif, casual atau santai, intim atau akrab. Berdasarkan beberapa pendapat di atas, dapat disimpulkan bahwa register adalah variasi bahasa yang digunakan menurut profesi seseorang dan mempunyai maksud tertentu serta memiliki kekhasan bahasa tersendiri.

Register adalah variasi bahasa berdasarkan bidang kegiatan atau pekerjaan seseorang (Chaer dan Agustina, 1995: 68). Register tampak dalam penggunaan kosakata. Setiap bidang kegiatan biasanya mempunyai sejumlah kosakata khusus atau tertentu yang tidak digunakan dalam bidang lain.

Register muncul pada bidang pekerjaan tertentu. Penggunaan variasi bahasa ini mempunyai karakteristik yang berbeda dengan bahasa yang digunakan oleh komunikasi lain. Wardaugh (1986) memaparkan bahwa register sebagai pemakaian kosakata khusus yang berkaitan dengan jenis pekerjaan atau kelompok masyarakat tertentu, seperti register kedokteran, pedagang, pegawai bank, karyawan pabrik, petani, pilot, operator taksi, salesman, guru, perawat, jurnalistik, dan lain sebagainya. Jadi, bahasa yang dipakai oleh seseorang yang berkecimpung dalam pekerjaan atau profesi tertentu mempunyai ciri khusus yang tidak dimiliki oleh pengguna bahasa lain.

Salah satu register yang ada di dalam masyarakat adalah register bahasa nelayan. Nelayan memiliki kosakata sendiri yang khas yang membedakan dengan profesi lainnya. Masyarakat yang bukan nelayan pun biasanya memahami kosakata mereka, jika anggota masyarakat tersebut berada dalam satu wilayah yang sama atau berdomisili di tempat yang sama dengan para nelayan. Orang yang tidak satu daerah dengan nelayan, kemungkinan tidak dapat memahami kosakata yang dimiliki oleh nelayan. Register nelayan ini timbul sebagai sarana komunikasi antar nelayan. 
Nelayan di Desa Munjungagung, Kramat, Tegal menggunakan bahasa Jawa dialek Tegal. Mereka memiliki register yang khas dan unik yang berbeda dengan nelayan dari daerah lainnya. Kosakata nelayan Desa Munjungagung digunakan dalam berkomunikasi dengan sesama nelayan, nelayan dengan keluarga, nelayan dengan tetangga dan teman.

Urgensi penelitian ini adalah untuk mendeskripsikan bentuk-bentuk kosakata khas dan unik yang hanya dimiliki oleh nelayan di Desa Munjungagung, Kramat, Tegal.

Penelitian tentang register nelayan pernah dilakukan, antara lain oleh Setianingsih (2013), Susanto (2018), dan Baehaqi (2019).

Susanto (2018) meneliti “ Register Nelayan di Desa Bendar, Kecamatan Juwana, Kabupaten Pati. Hasil penelitiannya menunjukkan bahwa ada bentuk kata dan frasa pada register bahasa yang digunakan oleh sekelompok nelayan. Fungsi-fungsi yang terdapat dalam daftar bahasa nelayan yaitu: (1) fungsi referensial, (2) fungsi konatif, (3) fungsi emotif, (5) fungsi fatik, (6) fungsi puitik. Pembentukan daftar nelayan bahasa sebagai hasil dari faktor (1) pengaturan, (2) Peserta, (3) berakhir, (4) Urutan Undang-Undang, (5) instrumental, dan (6) norma.

Baekhaqi (2019) dalam penelitiannya yang berjudul "Register nelayan di Desa Asemdoyong, Kabupaten Pemalang" menemukan mempunyai bentuk berdasarkan satuan lingual yaitu berupa kata, kata kompleks, dan idiom. Ditinjau dari asal bahasa, Nelayan di Desa Asemdoyong Kabupaten Pemalang berasal dari bahasa Jawa. Berdasarkan referen acuannya, register Nelayan di Desa Asemdoyong Kabupaten Pemalang. Faktor yang mempengaruhi penggunaan register ini berdasarkan analisis teori SPEKING adalah faktor Participant (penutur dan mitratutur), faktor instrumenalis (alat), dan faktor norm (norma atau aturan).

Penelitian ini memiliki persamaan dengan penelitian-penelitian sebelumnya yaitu mengkaji bentuk regsiter nelayan. Perbedaannya adalah pada subjek penelitiannya. Penelitian ini subjeknya adalah masyarakat nelayan Desa Munjungagung, Kecamatan Kramat, Kabupaten Tegal. Subjek penelitian yang berbeda, akan menyebabkan data yang diperoleh juga berbeda.

\section{METODE}

Penelitian ini merupakan penelitian deskriptif kualitatif yaitu dengan mendeskripsikan register bahasa nelayan Desa Munjungagung yang berupa kosakata yang khas yang digunakan oleh para nelayan untuk berkomunikasi dengan sesama nelaya.

Dalam penelitian ini digunakan penyediaan data dengan metode simak yaitu dengan cara menyimak penggunaan bahasa (Mahsun, 2007 : 29). Metode simak diwujudkan dengan teknik sadap sebagai teknik dasar. Teknik lanjutannya adalah teknik simak libat cakap dan teknik catat. Peneiti menyadap penggunaan bahasa nelayan di Desa Munjungagung, Kramat, Tegal. Teknik simak libat cakap digunakan, karena peneliti terlibat dalam peristiwa tutur utnuk menggali data tentang register yang digunakan oleh nelayan di desa tersebut. Langkah selanjutnya adalah mencatat data-data yang diduga terdapat register di Desa Munjungagung, Kramat, Tegal.

Metode yang digunakan dalam menganalisis data penelitian ini adalah metode padan yaitu metode analisis data yang alat penentunya di luar bahasa, terlepas dan tidak menjadi bagian dari bahasa yang bersangkutan atau diteliti (Sudaryanto dalam Kesuma, 2007: 47). Metode padan yang digunakan dalam penelitian ini adalah metode padan translasional yaitu metode padan yang alat penentunya berupa bahasa lain dan metode padan pragmatis yaitu metode padan yang alat penentunya adalah lawan atau mitra bicara. Metode ini digunakan untuk menentukan bentuk register di Desa Munjungagung, Kramat, Tegal.

Metode penyajian hasil analisis data dalam penelitian ini menggunakan metode penyajian informal yaitu data yang disajikan menggunakan kata-kata biasa (Sudaryanto, 1993: 145). Dalam penyajian data ini ditampilkan bentuk register nelayan di Desa Munjungagung, Kramat, Tegal yang berupa kosakata yang khas dan mendeskripsikan faktor penyebab munculya register nelayan di desa tersebut.

\section{HASIL DAN PEMBAHASAN}

Hasil penelitian tentang 'Register Nelayan di Desa Munjungagung, Kramat, Tegal' menunjukkan bahwa : 1) register nelayan berbentuk kosakata yang termasuk dalam kelas kata nomina, adjektiva, dan verba, 2) faktor penyebab digunakannya register nelayan adalah faktor sosial dan situasional. Faktor sosial berupa jenis pekerjaan yang sama yaitu nelayan, sedangkan faktor situasionalnya meliputi: penutur dan mitra tutur, sama-sama berprofesi sebagai nelayan, tempat pembicaraan di sekitar pantai, waktu pembicaraan pada saat mereka tidak melaut, dan pokok pembicaraannya berkisar tentang dunia nelayan. Berikut pembahasannya.

\section{Bentuk Register Nelayan Desa Munjungagung, Kramat, Tegal}

\section{a. Nomina}

Register nelayan di Desa Munjungagung, Kecamatan Kramat, Kabupaten Tegal berupa kosakata yang 
termasuk dalam kelas kata nomina berbentuk kata dasar dan kata kompleks. Kosakata tersebut antara lain: raman, pandega, jermudi, kratok, serep, seperti tampak dalam data berikut.

(1) Konteks : percakapan dua orang nelayan yang bertemu di jalan dekat pantai. Nelayan 1 melihat nelayan 2 membeli perbekalan melaut di warung sembako.
Nelayan 1
: "bisane tuku raman dewek, Toh?"
"kenapa beli raman sendiri, Toh?"
Nelayan 2
: "iya kiye wong wadon lagi mumet."
"iya ini istri saya sedang sakit kepala."

Percakapan di atas terjadi di warung sembako, pada saat nelayan 2 melihat nelayan 1 membeli perbekalan melaut. Kosakata khusus yang hanya digunakan oleh nelayan Desa Munjungagung pada tuturan di atas terdapat dalam kalimat "bisane tuku raman dewek toh?' yang diujarkan oleh nelayan 1. Kosakata khusus tersebut adalah 'raman' yang bermakna bahan-bahan makanan yang dijadikan sebagai perbekalan pada saat melaut. Perbekalan tersebut berisi beras, minyak, bumbu memasak ikan, gula, teh. Bahan-bahan makanan tersebut dibawa pada saat melaut untuk dimakan dan diminum di atas perahu. Bumbu digunakan untuk memasak ikan yang didapat di laut. Pada masayarkat umum tidak terdapat kata 'raman' yang digunakan dalam percakapan sehar-hari. Kata 'raman' termasuk dalam kelas kata nomina, karena merujuk pada benda yaitu bahan-bahan makanan untuk perbekalan melaut.

(2) Konteks : percakapan dua orang nelayan pemilik perahu tentang salah satu tetangga mereka yang memiliki perahu baru.

\begin{tabular}{|c|c|}
\hline Nelayan 1 & $\begin{array}{l}\text { : "Si Udin praune anyar?” } \\
\text { "Si Udin, perahunya baru?" }\end{array}$ \\
\hline Nelayan 2 & $\begin{array}{l}\text { : "iya jare pengin gadi jeragan.” } \\
\text { "iya, katanya pengin jadi jeragan." }\end{array}$ \\
\hline Nelayan 1 & $\begin{array}{l}\text { :"ganing duite akeh?" } \\
\text { "kok uangnya banyak?" }\end{array}$ \\
\hline Nelayan 2 & $\begin{array}{l}\text { :" utang Bank." } \\
\text { " hutang Bank." }\end{array}$ \\
\hline
\end{tabular}

Kosakata khusus nelayan Desa Munjungagung pada tuturan nelayan 1 dan nelayan 2 di atas adalah 'jeragan' yang terdapat dalam tutuan nelayan 2 " iya jare pengin gadi jeragan” ketika menjawab pertanyaan dari nelayan 1 tentang perahu Si Udin yang baru. Kosakata tersebut termasuk dalam kelas kata nomina yang berbentuk kata dasar yang berpadanan kata dengan 'juragan'. Kata tersebut, pada masyarakat umum bermakna orang yang dituankan atau majikan. Kata 'jeragan' bervariasi bentuk dengan kata 'juragan'. Pada masyarakat nelayan Desa Munjungagung, kata 'juragan'/jeragan' bermakna orang yang memiliki kapal atau perahu dan memiliki anak buah nelayan.

(3) Konteks : percakapan dua orang anak buah kapal yang masih muda tentang nahkoda yang diikuti oleh nelayan 2. Percakapan terjadi di dermaga Desa Munjungagung.
Nelayan
: "koen melu sapa Noh?"
" kamu ikut siapa, Noh?"
Nelayan 2
:" Soleh."
Nelayan 2
: "ora melu jermudi Sikus?”
" nggak ikut jurumudi Sikus?"
Nelayan $1 \quad$ : "kiye lagi pengin melu Soleh."
" ini lagi ingin ikut Soleh."

Dalam percakapan nelayan 1 dan 2 di atas terdapat kosakata register nelayan Desa Munjungagung yaitu kata 'jermudi' dalam tuturan nelayan 2 "ora melu jermudi Sikus?". Kata 'jermudi' berpadanan bentuk dengan kata 'jurumudi' atau nahkoda dalam bahasa Indonesia yang bermakna orang yang mengemudikan kapal. Biasanya kapal yang dikemudikan bukan kapal kecil atau perahu tetapi kapal besar yang berlayar dalam waktu lama. Selain kata 'jermudi', variasi bentuk "jurumudi' juga biasa digunakan dalam masyarakat nelayan Desa Munjungagung. Kata 'jermudi'/ 'jurumudi' termasuk dalam kelas kata nomina, karena merujuk pada benda yaitu orang yang memiliki perahu. Pada masyarakat umum, kata tersbut tidak digunakan. 
(4) Konteks : percakapan dua orang nelayan setengah baya tentang uang hasil melaut. Percakapan terjadi di parkiran sepeda dekat dermaga pada saat mereka pulang melaut.

\begin{tabular}{|c|c|}
\hline Nelayan 1 & $\begin{array}{l}\text { "bagen pira, Dih?" } \\
\text { "dapat berapa, Dih? }\end{array}$ \\
\hline Nelayan 2 & $\begin{array}{l}\text { : "kur sewidak." } \\
\text { " cuma enam puluh." }\end{array}$ \\
\hline Nelayan 1 & $\begin{array}{l}\text { : "ora kaya balikan wingi ya." } \\
\text { " nggak seperti kemarin, ya." }\end{array}$ \\
\hline Nela & $\begin{array}{l}\text { : "iya kiye akeh sing kosong." } \\
\text { "iya, ini banyak kosongnya." }\end{array}$ \\
\hline
\end{tabular}

Kata 'bagen' yang terdapat dalam tuturan interogatif nelayan 1 di atas tidak terdapat dalam penggunaan bahasa keseharian masyarakat umum, karena kata tersebut merupakan kosakata khusus yang digunakan oleh nelayan Desa Munjungagung. Kata 'bagen' termasuk dalam kelas kata nonima yang berbentuk kata turunan yang berasal dari kata 'bagi' yang bermakna dijadikan beberapa bagian dari bagian utuhnya. Kata 'bagi' mendapat sufiks $\{$-an\} menjadi bagian dan dalam bahasa Jawa kata tersebut adalah 'bagen'. Dalan tuturan nelayan 1 "bagen pira, Dih?", kata 'bagen' bermakna sama dengan bahasa Indonesia yaitu bagian yang maksudnya adalah bagian (uang) yang didapatkan oleh nelayan sesuai dengan hasil tangkapan ikannya. Apabila hasil melautnya banyak, 'bagennya' banyak, sedangkan apabila hasil tangkapan ikannya dapat sedikit, maka 'bagennya' sedikit.

\section{b. Verba}

Di dalam tuturan nelayan Desa Munjungagung ditemukan kosakata khas yang termasuk dalam kelas kata verba, karena merujuk pada suatu kegiatan melaut. Kosakata tersebut antara lain: 'nyadran', 'ngarad', 'tawur', dan 'kembara'. Kosakata tersebut tampak dalam tuturan nelayan berikut.

(5) Konteks : percakapan tiga orang nelayan pemilik perahu tentang sedekah laut. Percakapan terjadi di dermaga kapal pada sore hari.
Nelayan 1
: "Nar praune koen melu nyadran?"
"Nar, perahu kamu ikut nyadran?"
Nelayan 2 : "ya mengko angger ana rejeki ya melu."
"ya nanti kalau ada rejeki, ikut."
Nelayan 1
: "ya apa niate."
" bergantung niat."
Nelayan 2
: " Tha mbokan mengko ora along-along sih?"
" barangkali nanti nggak dapat banyak sih?"
Nelayan 3
: " enyong tah ora lah. Kayong belih nyandak. Gampang taun ngarep."
"saya nggak lah. Kayaknya nggak ikut. Tahun depan saja."

Percakapan tiga orang nelayan di atas membahas sedekah laut yang biasa digelar oleh nelayan Desa Munjungagung tiap tahun. Pada tuturan nelayan 1 di atas terdapat kosakata khusus nelayan Desa Munjungagung yaitu kata 'nyadran' dalam tuturan "Nar praune koen melu nyadran?". Kata 'nyadran' tersebut termasuk dalam kelas kata verba, karena merujuk pada suatu kegiatan. Dalam masyarakat umum, kosakata juga digunakan, tidak hanya dalam profesi tertentu. Misal, kata 'nyadran' digunakan sebagai istilah untuk 'nyekar' atau berkunjung ke makam keluarga atau orang tua yang sudah meninggal. Kata 'nyadran' juga digunakan sebagai istilah untuk mengunjungi orang tua atau keluarga pada saat lebaran. Di dalam masyarakat Desa Munjungagung yang berprofesi sebagai nelayan, kata tersebut merujuk pada suatu bentuk kegiatan persembahan kepada Tuhan Yang Maha Esa sebagai bentuk rasa syukur, karena telah memberi rezeki yang berlimpah melalui hasil melaut. 'Nyadran' juga bersinonim dengan sedekah laut. Kegiatan tersebut dilakukan setahun sekali, dengan ritual membuang sesajen ke tengah laut, diiringi dengan pagelaran wayang.

(6) Konteks : percakapan dua oran nelayan tentang tangkapan hasil melaut hari itu. Percakapan terjadi di dermaga pada sore hari.

$$
\begin{array}{ll}
\text { Nelayan } 1 & \text { : “ngarad, Mo?" } \\
& \text { "ngarad, Mo?" } \\
\text { Nelayan } 2 & \text { : "iya mau." }
\end{array}
$$




$$
\begin{array}{ll}
\text { Nelayan } 1 & \text { " } \\
\text { : "oliha tadi." } & \text { " dapat?" } \\
\text { Nelayan } 2 & \text { : "ya lumayanan." } \\
& \text { "ya lumayan." }
\end{array}
$$

Percakapan nelayan 1 dan 2 di atas terjadi di dermaga Desa Munjungagung. Nelayan 1 menanyakan apakah nelayan 2 berangkat melaut, seperti tampak dalam tuturan "ngarad, Mo?'. Kata 'ngarad' yang terdapat dalam kalimat interogatif nelayan 1 tersebut merupakan register khusus nelayan Desa Munjungagung yang berbentuk termasuk dalam kelas kata verba, karena merujuk pada kegiatan menangkap ikan. Kata 'ngarad' bermakna kegiatan melaut dengan alat tangkat berupa jaring yang dapat menjaring udang. Melaut dengan cara 'ngarad' ini biasanya dilakukan pada maam hari dan hanya dilakukan oleh satu orang saja yaitu pemilik perahu tanpa ada anak buah kapalnya. Melaut dengan cara 'ngarad' ini merupakan kegiatan melaut yang paling sederhana, karena hanya dijalankan oleh satu orang saja, tanpa bantuan oleh orang lain. Dalam masyarakat umum tidak terdapat kata 'ngarad'.

(7) Konteks : percakapan dua orang nelayan pemiliki perahu ketika melihat salah satu perahu milik nelayan sudah mendarat sebelum waktu mendarat tiba.

$$
\begin{aligned}
& \text { Nelayan } 1 \text { : "kae Parto wis balik. Apa ora tawur?” } \\
& \text { " itu Parto sudah pulang. Apa nggak tawur?” } \\
& \text { Nelayan } 2 \text { : “la ngarti ombake gede mangkat bae." } \\
& \text { "sudah tahu ombaknya besar tetap berangkat." }
\end{aligned}
$$

Pada tuturan nelayan 1 di atas terdapat kata 'tawur' yang merupakan kosakata khas nelayan Desa Munjungagung yang termasuk dalam kelas kata verba. Dilihat dari bentuknya, kata 'tawur' berbentuk kata dasar. Kata 'tawur' tersebut terdapat dalam tuturan 'kae Parto wis balik, apa ora tawur?' ketika melihat salah satu teman mereka sesama nelayan, pulang dari melaut pada pukul delapan pagi. Biasanya nelayan pulang melaut pukul mulai pukul sebelas siang. Jika pulang kurang dari waktu tersebut, apalagi pulang pagi, maka dapat dipastikan bahwa hasil tangkapan ikannya hari itu kosong. Kata 'tawur' dalam masyarakat umum tidak digunakan, sedangkan pada masyarakat nelayan Desa Munjungagung bermakna menyebarkan jaring di laut.

(8) Konteks : percakapan dua orang nelayan setengah baya tentang waktu keberangkatan melaut perahu milik nelayan 2.

$$
\begin{aligned}
& \text { Nelayan } 1 \text { : "Met, mbesiki pan kembara jam pira?" } \\
& \text { " Met, besok mau kembara jam berapa?" } \\
& \text { Nelayan } 2 \text { : “jam rolasan.” } \\
& \text { " jam dua belasan." } \\
& \text { Nelayan } 1 \text { : “ enyong melu nyimbat lhen." } \\
& \text { "saya ikut nyimbat ya." } \\
& \text { Nelayan } 2 \text { : "gari mangkat ka." } \\
& \text { " tinggal berangkat saja kok." }
\end{aligned}
$$

Pada tuturan dua orang nelayan di atas, terlihat tuturan 'Met, mbesiki pan kembara jam pira?' yamg dituturkan oleh nelayan 1 yang mengandung kosakata khusus register nelayan. Kata tersebut adalah 'kembara' yang termasuk dalam kelas kata verba, karena merujuk pada kegiatan berangkat melaut. Waktu 'kembara' disesuaikan dengan jenis perahu dan alat tangkap ikannya. Perahu jenis 'lautan', 'kembara' pada siang hari sekitar pukul sebelas siang. Perahu jenis 'nggemplo' waktu 'kembara' seteleh waktu subuh, sebelum matahari terbit yaitu sekitar pukul lima pagi. Perahu jenis 'ngursin', kembara pukul 10 siang, hampir sama seperti jenis lautan. Dalam masyarakat umum, kata 'kembara' tidak digunakan dalam komunikasi sehari-hari, karena tidak terdapat kata tersebut.

\section{c. Adjektiva}

Di dalam tuturan nelayan Desa Munjungagung ditemukan kosakata yang termasuk dalam kelas kata adjektiva. Jumlah register yang termasuk adjektiva sangat sedikit, tidak seperti kelas kata nomina dan verba, yang antara lain terdapat dalam bahasan berikut.

(9) Konteks : percakapan tiga orang anak buah kapal di warung makan dekat dermaga tentang hasil tangkapan ikan hari ini.

Nelayan 1 : " mau miyange along, Man?"

$$
\text { " tadi along, Man?" }
$$




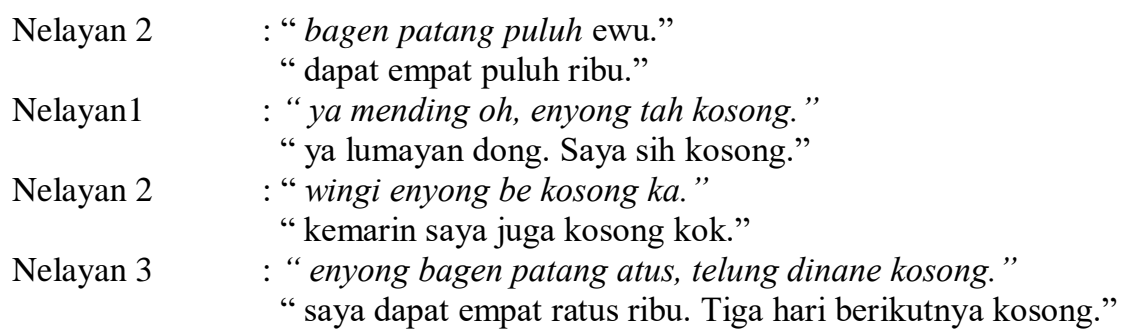

Tuturan tiga orang nelayan di atas terjadi di warung makan. Nelayan 1 menanyakan hasil tangkapan ikan Nelayan 2 apakah hari ini dapat banyak atau tidak yang terdapat dalam tuturan "mau miyange along, Man?" Kata 'along' pada tuturan nelayan 1 tersebut termasuk dalam kelas kata adjektiva yang memiliki makna keadaan melaut dengan perolehan banyak tangkapan ikannya. Kata 'along' merupakan kata khusus nelayan munjungagung yang tidak ditemukan pada masyarakat umum. Kata 'along' biasanya digunakan untuk saling menayakan hasil tangkapan ikan antarsesama nelayang. Jika 'along', maka tangkapan ikannya dapat banyak, sedangkan 'ora along' berarti tangkapan ikannya sedikit. Kata 'along' digunakan untuk membandingkan perolehan tangkapan ikan antara nelayan satu degan lainnya.

\section{Faktor Penyebab Munculnya Register Nelayan di Desa Munjungagung, Kramat, Tegal}

Faktor Penyebab munculnya register nelayan yang berupa kosakata khas yang hanya digunakan oleh nelayan Desa Munjungagung dalam berkomunikasi dengan sesama nelayan adalah faktor sosial dan faktor situasional. Faktor sosial yang menyebabkan adalah pekerjaan yaitu nelayan.

\section{1) Faktor Sosial}

Faktor sosial mengacu pada kehetoregenan anggota masyarakat tutur baik ditinjau dari usia, jenis kelamin, pekerjaan, pendidikan, status sosial atau kemampuan sosial ekonomi dan berbagai kegiatan. Faktor sosial yang menyebabkan munculnya register nelayan di Desa Munjungagung, Kramat Tegal adalah bidang pekerjaan yang sama, yaitu nelayan. Nelayan akan menggunakan kosakata khas tersebut untuk berkomunikasi dengan sesama nelayan, karena memiliki bidang pekerjaan atau profesi yang sama. Kosakata khas tersebut tentunya hanya dipahami oleh orang yang berprofesi sama yaitu nelayan. Jika bukan orang yang berprofesi sebagai nelayan, tidak akan mengetahui kosakata tersebut. Apabila diucapkan oleh nelayan pun, kata tersebut tidak akan dipahami oleh masyarakat yang bukan nelayan. Kosakata khusus tersebut antara lain tampak dalam data yang berupa penggalan-penggalan tuturan nelayan berikut:

1) "bisane tuku raman dewek, Toh?"

2) "Wa, sampeyan motorise pira?"

3) " pandegane koen rupane ana sing anyar? Wong endi kae."

4) “iya jare pengin gadi jeragan."

5) " ora melu jermudi Sikus?"

6) " gadi kratok?"

7) “Rus koen miyen tah tau gadi serepe Manis oya?"

8) taukene wong endi?

9) "kursinan lagi along-along ora, Man?"

10) " ngobor ayawene wis pada balik ya."

Kosakata raman, motoris, pandega, jeragan, jermudi, kratok, serep, tauke, kursin, ngobor tuturan nelayan di atas adalah kosakata khas yang hanya digunakan oleh sesama nelayan Desa Munjuangagung dalam berkomunikasi. Selain orang yang berprofesi sebagai nelayan, tentunya tidak akan mengenal kosakata tersebut. Dalam masyarakat umum pun, kosakata tersebut tidak digunakan untuk berkomunikasi. Hal ini, karena nelayan memiliki kosakata yang khas yang hanya dipahami oleh sesama nelayan.

\section{2) Faktor Situasional}

Di dalam masayarakat nelayan Desa Munjunagung, faktor situasional yang menyebabkan digunakannya register khas nelayan adalah penutur yang berprofesi sebagai nelayan dengan lawan bicara yang sama-sama berprofesi sebagai nelayan. Pembicaan dilakukan pada sore hari ketika mereka tidak sedang melaut dan bertempat di tempat para nelayan sering berkumpul yaitu di warung makan dekat dermaga atau dekat Tempat Pelelangan Ikan, di dermaga, di tempat parkir sepeda motor (tempat penitipan motor khusus nelayan), di rumah nelayan, dan di warung sembako. Pokok pembicaraan para nelayan 
tersebut berkisar seputar kegiatan-kegiatan dalam melaut yang hanya dapat dipahami oleh orang yang berprofesi sebagai nelayan.

\section{SIMPULAN} bahwa:

Berdasarkan hasil penelitian 'Register Nelayan di Desa Munjungagung, Kramat, Tegal' dapat disimpulkan

1. Register nelayan Desa Munjungagung berbentuk kosakata khas yang termasuk dalam kelas kata nomina, adjektiva, dan verba

2. Faktor penyebab digunakannya register nelayan adalah faktor sosial dan situasional. Faktor sosial berupa jenis pekerjaan yang sama yaitu nelayan, sedangkan faktor situasionalnya meliputi: penutur dan mitra tutur, samasama berprofesi sebagai nelayan, tempat terjadinya pembicaraan di sekitar pantai, waktu pembicaraan pada saat mereka tidak melaut, dan pokok pembicaraannya berkisar tentang dunia nelayan.

\section{DAFTAR PUSTAKA}

Baehaqi, M, Rafi. (2019). Register Nelayan Desa Asemdoyong, Kabupaten Pemalang. Tesis. Semarang. Unnes. Chaer, Abdul dan Leoni Agustina. (1995). Sosiolinguistik Perkenalan Awal. Jakarta: PT Rineka Cipta.

Chaer, Abdul dan Leoni Agustina. (2010). Sosiolinguistik Perkenalan Awal. Jakarta: PT Rineka Cipta

Chaer, Abdul. (2014). Linguistik Umum. Jakarta : PT. Rineka Cipta.

Kusuma, Tri Mastoyo Jati. (2007). Pengantar (Metode) Penelitian Bahasa. Yogyakarta: Carasvatibooks.

Mahsun. (2007). Metode Penelitian Bahasa: Tahapan, Strategi, dan Tekniknya. Jakarta: Grafindo Persada.

Moleong, L.J. (2007). Metodologi Penelitian Kualitatif. Bandung: PT Remaja Rosdakarya.

Pateda, Mansoer. (1987). Sosiolinguistik. Bandung. Angkasa.

Sudaryanto. (1993). Metode dan Aneka Teknik Analisis Bahasa. Yogyakarta: Duta Wacana University Press.

Susanto, Hari Bakti dan Deby Luriawati. (2018). Register Nelayan di Desa Bendar Kecamatan Juwana Kabupaten Pati. Jurnal Sastra Indonesia. Vol 7 no 1 (2018).

https://journal.unnes.ac.id/sju/index.php/jsi/article/view/29813. (6 Februari 2021)

Wardhaugh, Ronald. (1986). An Introduction to Sociolinguistics. Oxford: Basil Blackwel. 